\title{
RAINFALL REGIME ON FINE ROOT GROWTH IN A SEASONALLY DRY TROPICAL FOREST ${ }^{1}$
}

\author{
EUNICE MAIA DE ANDRADE ${ }^{2 *}$, GILBERTO QUEVEDO ROSA ${ }^{3}$, ALDENIA MENDES MASCENA DE ALMEIDA ${ }^{3}$, \\ ANTONIO GIVANILSON RODRIGUES DA SILVA ${ }^{3}$, MARIA GINA TORRES SENA ${ }^{3}$
}

\begin{abstract}
Seasonally dry tropical forests (SDTF) usually present dry seasons of eight or more months. Considering the concerns about the resilience of SDTF to climate changes, the objective of this study was to evaluate the effect of the rainfall regime on fine root growth in a SDTF. The experiment started at the end of the wet season (July 2015), when fine roots were evaluated and ingrowth cores were implemented. The temporal growth of fine roots in the $0-30 \mathrm{~cm}$ soil layer was monitored, considering the $0-10,10-20$, and 20-30 $\mathrm{cm}$ sublayers, through six samplings from November 2015 to July 2017. The characteristics evaluated were fine root biomass, fine root length, fine root specific length, and fine root mean diameter. The significances of the root growths over time and space were tested by the Kruskal-Wallis test $(p<0.05)$. Fine roots $(\varnothing<2 \mathrm{~mm})$ were separated and dried in an oven $\left(65^{\circ} \mathrm{C}\right)$ until constant weight. The root length was determined using the Giaroots software. The fine root biomass in July 2015 was $7.7 \pm 5.0 \mathrm{Mg} \mathrm{ha}^{-1}$ and the length was $5.0 \pm 3.2 \mathrm{~km} \mathrm{~m}^{-2}$. Fine root growth in SDTF is strongly limited by dry periods, occurring decreases in biomass and length of fine roots in all layers evaluated. Fine root growth occurs predominantly in rainy seasons, with fast response of the root system to rainfall events, mainly in root length.
\end{abstract}

Keywords: Caatinga. Semiarid. Rainfall regime. Effective depth.

\section{DINÂMICA DA PRODUÇÃO DE RAÍZES FINAS EM FLORESTA TROPICAL SAZONALMENTE SECA ANTE O REGIME PLUVIOMÉTRICO}

\begin{abstract}
RESUMO - Florestas tropicais sazonalmente secas (FTSS) geralmente apresentam estações secas com oito ou mais meses. Frente ao questionamento de resiliência das FTSS às mudanças climáticas desenvolveu-se essa pesquisa objetivando investigar a dinâmica da biomassa de raízes finas ante o regime pluviométrico. $O$ experimento teve início ao final da estação úmida (jul./2015), quando as raízes finas foram caracterizadas e implantados os núcleos de crescimento interno. A dinâmica temporal das raízes finas foi monitorada na camada de 0-30 cm e as subcamadas de 0-10, 10-20 e 20-30 cm por seis coletas no período de nov./2015 a jul./2017. Os indicadores considerados na investigação foram: biomassa de raízes finas, comprimento de raízes finas, comprimento específico de raízes finas, e diâmetro médio das raízes finas. A significância da dinâmica das raízes no tempo e no espaço foram testadas pelo teste Kruskal-Wallis $(p<$ $0,05)$. Após a separação, as raízes finas $(\varnothing<2 \mathrm{~mm})$ foram secas em estufa $\left(65^{\circ} \mathrm{C}\right)$ até massa constante. $\mathrm{O}$ comprimento das raízes foi determinado pelo software Giaroots. A biomassa de raízes finas $(\varnothing<2 \mathrm{~mm})$ em jul./2015 foi de 7,7 $\pm 5,0$ $\mathrm{Mg} \mathrm{ha}^{-1}$ e o comprimento foi de 5,0 $\pm 3,2 \mathrm{~km} \mathrm{~m}^{-2}$. A dinâmica das raízes finas em FTSS é fortemente limitada nos períodos secos, ocorrendo perda de biomassa e do comprimento de raízes finas em todas as camadas. A produção de raízes finas ocorre fundamentalmente nas estações chuvosas, com uma rápida resposta de desenvolvimento do sistema radicular à ocorrência de precipitações, principalmente no seu comprimento.
\end{abstract}

Palavras-chave: Caatinga. Semiárido. Regime pluviométrico. Profundidade efetiva.

\footnotetext{
${ }^{*}$ Corresponding author

${ }^{1}$ Received for publication in $10 / 02 / 2019$; accepted in $03 / 17 / 2020$.

Paper extracted from the master dissertation of the second author.

${ }^{2}$ Department of Soil and Water Conservation, Universidade Federal do Semi-Árido, Mossoró, RN, Brazil; eandrade.ufc.@gmail.com ORCID: 0000-0002-9750-0364.

${ }^{3}$ Department of Agricultural Engineering, Universidade Federal do Ceará, Fortaleza, CE, Brazil; gilbertoquevedorosa@gmail.com ORCID:0000-0002-0545-666X, ald_m_m@hotmail.com - ORCID:0000-0003-0929-1513, givanilsonrodrigues20@gmail.com ORCID:0000-0001-9644-5642, ginasenaa@gmail.com - ORCID:0000-0002-8406-8728.
} 


\section{INTRODUCTION}

Fine roots $(\varnothing<2 \mathrm{~mm})$ are essential for the plant's life; they are responsible for the process of absorption of water and nutrients available in the soil (FRESCHET et al., 2017; IVERSEN et al., 2017), which makes them essential components of the ecosystem. The importance of fine roots is due to their contribution to biomass production (THAKUR et al., 2019) and soil organic C absorption (SOLLY et al., 2018; AQUINO et al., 2017). Several studies have been developed in different parts of the world focused on the importance of these functions in inland ecosystems, mainly in tropical (METCALFE et al., 2008; KATAYAMA et al., 2019) and temperate forests (ANDREASSON et al., 2016; PINNO et al., 2010; SOLLY et al., 2018). However, few information is found for tropical dry forests (ALLEN et al., 2017, MAASS; BURGOS, 2011, PINHEIRO; COSTA; ARAÚJO, 2013), although Murphy and Lugo (1986) had shown that the percentage of total biomass in roots of dry forests is higher than that in rainforests. Costa et al. (2014) confirmed this result; they found roots of tropical dry forests concentrating 53 to $63 \%$ of their total biomass.

This information denotes the importance of roots for carbon stock in tropical dry forests (ASSEFA et al., 2017; PEREIRA JÚNIOR et al., 2016). Moreover, this component is less studied than those above the soil (ERKTAN; MCCORMACK; ROUMET, 2018). Possible reasons for this lack of studies on roots are (i) the fact that roots are within the complex soil matrix and their sampling is difficult (ERKTAN; MCCORMACK; ROUMET, 2018), mainly fine roots; (ii) methodologies for root development monitoring are laborious and require high investments (ANDREASSON et al., 2016; IVERSEN et al., 2017); (iii) and there is no methodology universally appropriate for root sampling (KATAYAMA et al., 2019).

Therefore, studies on these issues are needed, mainly in seasonally dry tropical forests (SDTF), whose characteristic water deficit conditions might be aggravated due to climate changes (CASTANHO et al., 2020). Studies on fine root growth enable the development of graphs that explain the root system response to climate seasonality (ADIKU et al.; 2000; METCALFE et al., 2008; WIJK, 2011).

The predominant climate in SDTF in the Northeast of Brazil is semiarid hot, which is characterizing by poor temporal and spatial rainfall distribution (ANDRADE et al., 2017), with frequent dry years, and consecutive dry days during the rainy season (ANDRADE et al., 2016). The rainfall irregularity combined with high temperatures and potential evapotranspiration results in periods with low soil moisture (MENDES et al., 2013; COSTA et al., 2013) that affect the development of plant species in the SDTF (ALLEN et al., 2017; PINHEIRO; COSTA; ARAÚJO, 2013). Thus, a better understanding of process and relations between fine root development and rainfall seasonality in these environments is needed. Therefore, the objective of this study was to evaluate the effect of the rainfall regime on fine root growth in a SDTF

\section{MATERIAL AND METHODS}

\section{Study area}

The study was conducted in a fragment of a seasonally dry tropical forest $\left(3^{\circ} 47^{\prime} \mathrm{S}, 39^{\circ} 16^{\prime} \mathrm{W}\right)$ in the Caatinga phytogeographic domain (SDTF-CPD), in the Curu Valley Experiment Farm of the Federal University of Ceará (Figure 1), Brazil. The native vegetation was substituted by Cenchrus ciliares crops, which were grown from 1974 to 1984 and used as pastures for bovine animals. The animals were removed from the area in 1985, when the regeneration of the native vegetation began. Therefore, at the beginning of the study (July 2015), the area had been under process of regeneration for 31 years. A phytosociological surveying showed that the predominate species in the area were Sebastiania macrocarpa Muell. Arg., Bauhinia cheilantha (Bong.) Steud., Piptadenia stipulacea (Benth.) Ducke, and Croton blanchetianus Bail. 


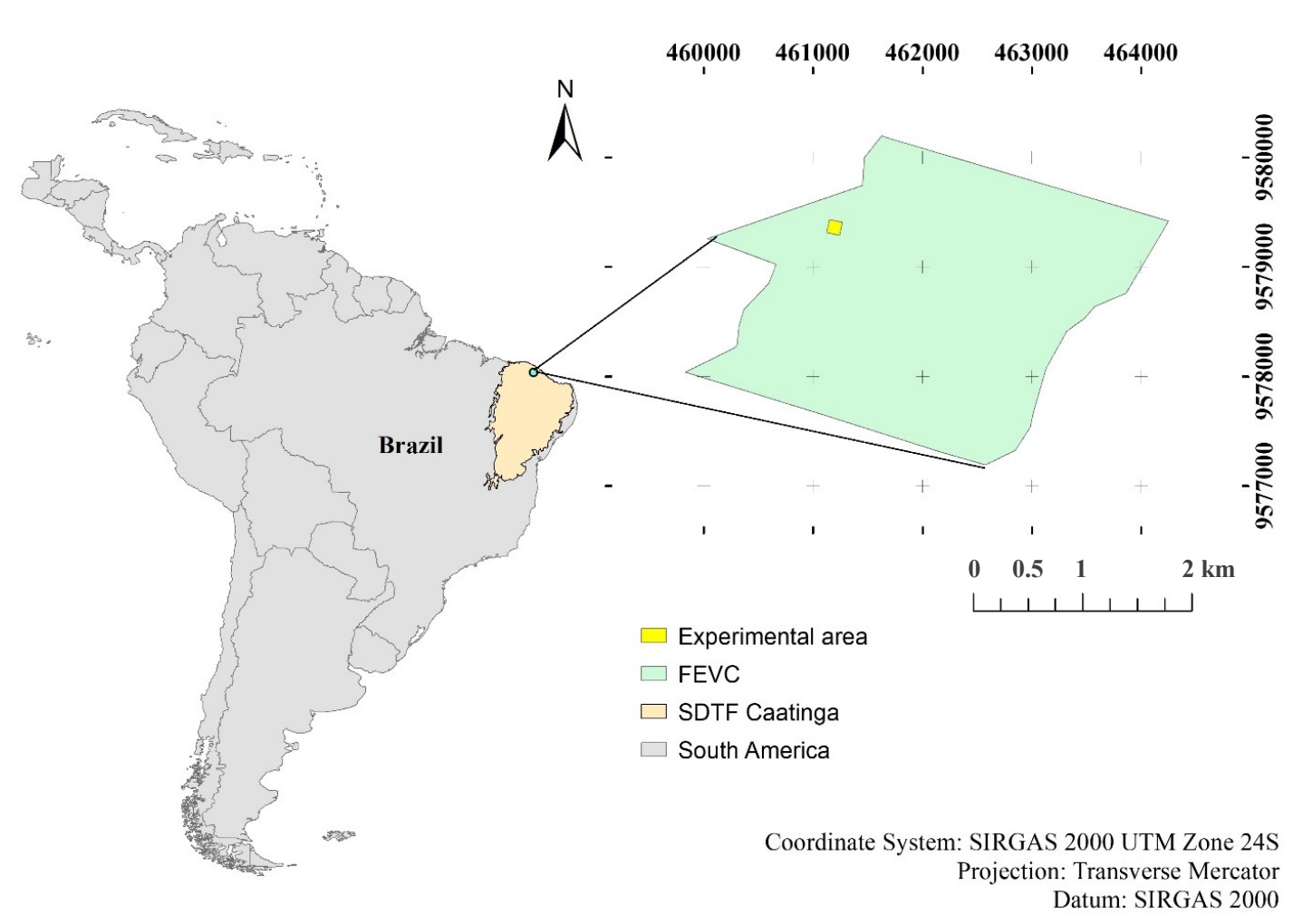

Figure 1. Location of the study area.

The soil of the area was classified (SANTOS et al., 2018), as Luvissolo (Alfisol), which presented a sandy-loam texture with higher density in deeper layers (Table 1). The climate of region is BSw'h', semiarid hot with rainy autumn, according to the Köppen classification, presenting monthly mean temperatures above $18{ }^{\circ} \mathrm{C}$. The mean annual rainfall depth is $762 \mathrm{~mm}$, whose monthly distribution presents high temporal and spatial variability, which can be concentrated in one month with depths above those accumulated in a dry year (ANDRADE et al., 2016). The accumulated rainfall depths during the experiment in the rainy seasons were $686 \mathrm{~mm}$ (2015), $616 \mathrm{~mm}$ (2016), and $704 \mathrm{~mm}$ (2017) (Figure 2).

Table 1. Physical and chemical attributes of the soil of the study area.

\begin{tabular}{lcccc}
\hline Horizon & $\mathrm{A}$ & $\mathrm{AB}$ & $\mathrm{Bt} 1$ & $\mathrm{Bt2}$ \\
\hline Layer $(\mathrm{cm})$ & $0-10$ & $10-20$ & $20-50$ & $50-80+$ \\
\hline Physical attributes & & & & \\
Sand $\left(\mathrm{g} \mathrm{kg}^{-1}\right)$ & 845 & 776 & 707 & 498 \\
$\mathrm{Silt}\left(\mathrm{g} \mathrm{kg}^{-1}\right)$ & 106 & 127 & 137 & 242 \\
Clay $\left(\mathrm{g} \mathrm{kg}^{-1}\right)$ & 49 & 97 & 156 & 261 \\
Chemical attributes & & & & \\
$\mathrm{pH}\left(\mathrm{H}_{2} \mathrm{O}\right) 1: 2.5$ & 5.67 & 5.46 & 5.90 & 5.90 \\
$\mathrm{Ca}^{2+}\left(\mathrm{cmolc} \mathrm{kg}^{-1}\right)$ & 3.30 & 1.60 & 1.80 & 3.50 \\
$\mathrm{Mg}^{2+}\left(\mathrm{cmolc} \mathrm{kg}^{-1}\right)$ & 1.60 & 1.10 & 1.20 & 1.60 \\
$\mathrm{~K}^{+}\left(\mathrm{cmolc} \mathrm{kg}^{-1}\right)$ & 0.10 & 0.14 & 0.14 & 0.10 \\
$\mathrm{Na}^{+}\left(\mathrm{cmolc} \mathrm{kg}^{-1}\right)$ & 0.04 & 0.04 & 0.05 & 0.05 \\
$\mathrm{~S}\left(\mathrm{cmolc} \mathrm{kg}^{-1}\right)$ & 4.03 & 2.88 & 3.19 & 5.39 \\
$\mathrm{Al}^{3+}\left(\mathrm{cmolc} \mathrm{kg}^{-1}\right)$ & 0.10 & 0.10 & 0.10 & 0.10 \\
$\mathrm{H}^{+}\left(\mathrm{cmolc} \mathrm{kg}^{-1}\right)$ & 0.50 & 2.00 & 1.10 & 0.70 \\
$\mathrm{CEC}^{\left(\mathrm{cmolc} \mathrm{kg}^{-1}\right)}$ & 5.63 & 4.98 & 4.39 & 6.19 \\
$\mathrm{BS}(\%)_{\mathrm{ESP}(\%)}$ & 89.35 & 57.84 & 72.66 & 87.07 \\
\hline
\end{tabular}

$\mathrm{CEC}=$ cation exchange capacity $\mathrm{BS}=$ base saturation; $\mathrm{ESP}=$ Exchangeable sodium percentage 


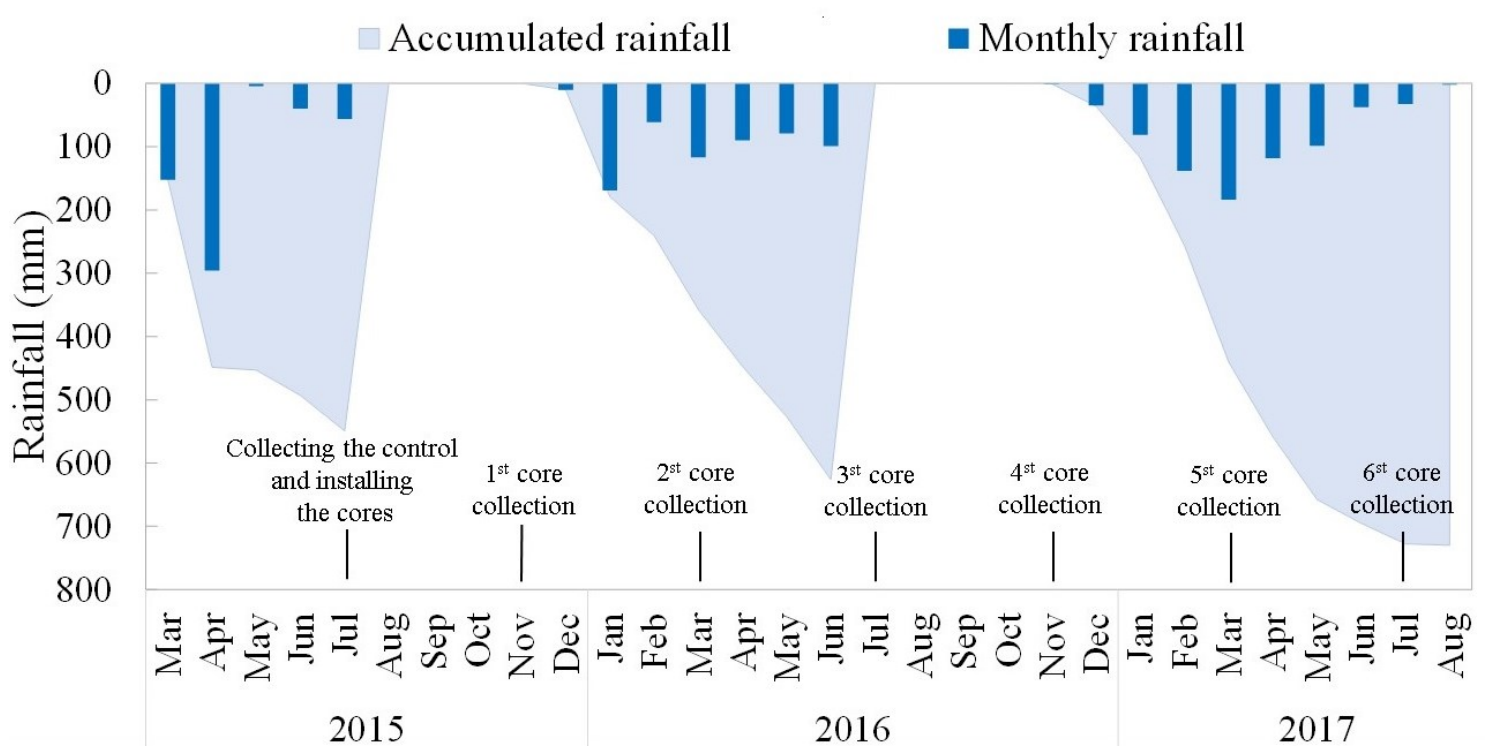

Figure 2. Monthly and accumulated rainfall depths during the experiment.

\section{Ingrowth Core Method}

The fine root growth was quantified using the Ingrowth Core method (PERSSON, 1983). The ingrowth cores are cylindrical high-density propylene bags $(14 \mathrm{~cm}$ diameter, $30 \mathrm{~cm}$ height, and $4.62 \mathrm{dm}^{3}$ volume) with mesh of $1.0 \mathrm{~cm}$ (Figure 3A). This method consists of removal of the soil to the desirable layer and sieving it for removal of roots (Figure 3B). The cores were inserted to a depth of 30 $\mathrm{cm}$ from the soil surface (Figure $3 \mathrm{C}$ ), because the effective depth of fine roots is lower than $36 \mathrm{~cm}$ (PINHEIRO; COSTA; ARAÚJO, 2013).

The soil free from roots was used to fill the cores, according to the removal order, i.e., the first layers were the latest to be added to the cores. The soil was removed to the depth of $30 \mathrm{~cm}$ or to the impediment layer, according to the sublayers of $0-10$ $\mathrm{cm} ; 10-20 \mathrm{~cm}$, and $20-30 \mathrm{~cm}$. The fine root growth after the implementation of the cores was used to estimate the fine root production in the field.

Figure 3. Stages of the methodology used in the study. (A) ingrowth cores made with polyethylene mesh; (B) opening of pits for insertion of the cores and separation of roots from the soil; (C) implementation and filling of the cores with soil; (D) collection of cores; (E) separation of roots from the soil; (F) root image preparation for measuring root length in the Giaroots software.
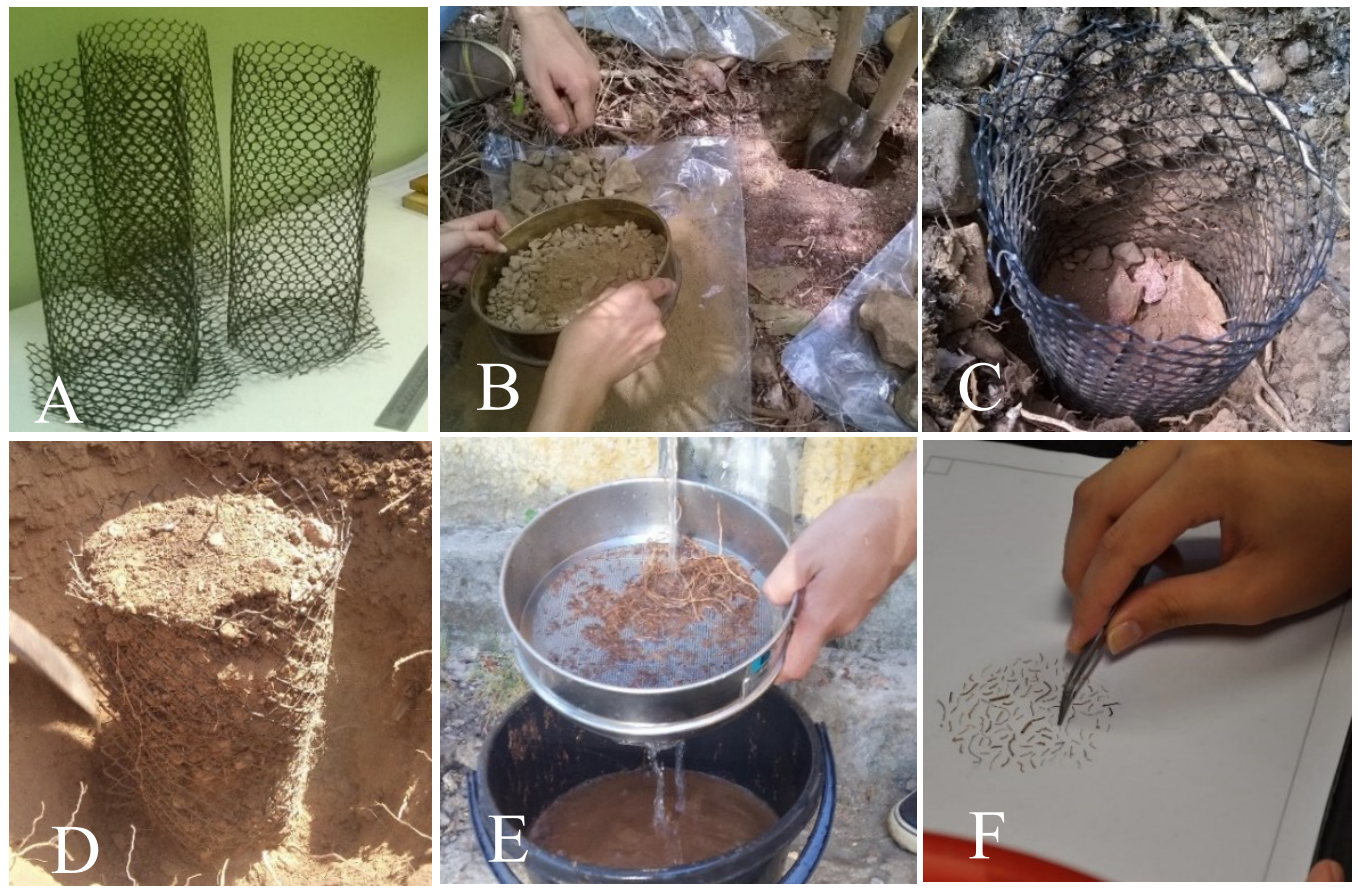

Rev. Caatinga, Mossoró, v. 33, n. 2, p. 458 - 469, abr. - jun., 2020 


\section{Fine root sampling}

In July 2015, 142 ingrowth cores with spacing of $10 \mathrm{~m}$ (1.42 ha) were implemented. The sampling of cores occurred from July 2015 to July 2017, with 4-month intervals, considering the local rainfall regime (Figure 2). The samplings in March represented the rainy season; those in July represented the rainy to dry season transition; and those in November represented the dry season.

Roots form 10 cores were collected during the implementation (July 2015) to characterize the natural condition of the roots in the SDTF fragment. These samples were used as control for comparisons. Six cores were randomly chosen and collected every 4 months. The collection of the core was done by inserting a metal blade into the soil outside the mesh (Figure 3D) to cut the roots that have penetrated the cores, and the cores were carefully withdrawn. The cores were divided into sublayers $(0-10 \mathrm{~cm}, 10-20$ $\mathrm{cm}$, and 20-30 cm). The samples were taken to the laboratory of the Federal University of Ceará, washed until the roots were free from soil (Figure $3 \mathrm{E}$ ), air dried for 48 hours, and then separated by shaking in a set of sieves of $2 \mathrm{~mm}$ and $1 \mathrm{~mm}$ (Figure $3 \mathrm{E})$. The roots were then dried in an oven $\left(65^{\circ} \mathrm{C}\right)$ until constant weight and weighed. The root length was analyzed through photographs (Figure 3F), using the Giaroots software (GALKOVSKYI et al., 2012)

\section{Data analysis}

The data were analyzed for total fine roots in the $0-30 \mathrm{~cm}$ soil layer, considering the $0-10,10-20$, and 20-30 $\mathrm{cm}$ sublayers, and roots with diameter lower than $2 \mathrm{~mm}(\varnothing<2 \mathrm{~mm})$, considering the subdivisions of this class $(\varnothing<1 \mathrm{~mm}, 1<\varnothing<2 \mathrm{~mm})$. The variables evaluated were: fine root biomass $\left(\mathrm{FRB} ; \mathrm{Mg} \mathrm{ha}^{-1}\right.$ ), fine root length (FRL; $\mathrm{km} \mathrm{m}^{-2}$ ), fine root specific length (FRSL; $\mathrm{km} \mathrm{kg}^{-1}$ ), and fine root mean diameter (FRD; $\mathrm{mm}$ ). The effect of climate seasonality was evaluated using the coefficient of correlation of Spearman between the root growth variables (FRB, FRL, FRD, FRSL) and variables related to water availability: 3-month accumulated rainfall before collection (3MAR), 4-month accumulated rainfall before collection (4MAR), number of days with rainfall within 3 months before collection (DWR3), number of days with rainfall within 4 months before collection (DWR4), number of days with rainfall above $5 \mathrm{~mm}$ within 3 months before collection (DWR3 $>5$ ), and number of days with rainfall above $5 \mathrm{~mm}$ within 4 months before collection (DWR4 $>5$ ). The data were analyzed for normal distribution by the Shapiro Wilk test $(p \leq 0.05)$ and the Kruskal-Wallis H test $(p \leq 0.05)$.

\section{RESULTS AND DISCUSSION}

\author{
Temporal fine root growth in the $0-30 \mathrm{~cm}$ soil \\ layer
}

The fine root biomass (FRB) in the $0-30 \mathrm{~cm}$ soil layer in the 2-year period is shown in (Table 2). The mean FRB $(\varnothing<2 \mathrm{~mm})$ in the control collection (July 2015) was $7.7 \pm 5.0 \mathrm{Mg} \mathrm{ha}^{-1}$; the roots were mainly from the $1<\emptyset<2 \mathrm{~mm}$ class $\left(4.8 \pm 2.8 \mathrm{Mg} \mathrm{ha}^{-1}\right)$. Fine roots are characterized by constant death, tissues decomposition, and formation of new roots (PEREIRA JÚNIOR et al., 2016; AQUINO et al., 2017).

The absence of root formation from August 2015 to November 2015 was due to the low soil moisture (MENDES et al., 2013) during the dry season (Figure 2). Significant moisture decreases hinder new root production mainly due to changes in the system root turgor (SOLLY et al., 2018; ALLEN et al., 2017; BEJARANO et al., 2010; METCALFE et al, 2008). Stomata are closed due to the water deficit during the dry season, followed by leaf senescence and absence or near zero photosynthesis rates (ALLEN et al., 2017). Therefore, there is no production of new absorption roots because the soil presents no available water to plants.

The mean FRB $\left(1.4 \pm 0.6 \mathrm{Mg} \mathrm{ha}^{-1}\right)$ and FRL $\left(1.5 \pm 0.4 \mathrm{~km} \mathrm{~m}^{-2}\right)$ from November 2015 to March 2016 were predominantly of the $\varnothing<1 \mathrm{~mm}$ class $\left(0.8 \pm 0.3 \mathrm{Mg} \mathrm{ha}^{-1}\right)$ and $\left(0.8 \pm 0.3 \quad \mathrm{~km} \mathrm{~m}^{-2}\right)$ respectively. Thus, the accumulated rainfall of 247.1 $\mathrm{mm}$, (Figure 2) in the beginning of the rainy season was enough to improve the root biomass production, mainly very fine roots, as reported by Solly et al (2018). The root diameter classes had no effect on the FRSL over time, denoting that the $247.1 \mathrm{~mm}$ rainfall in the first three months of the rainy season promoted a recovery of the root length, which presented no significant differences in July 2015. In the first months evaluated, when the roots started to develop, there was a higher investment in elongation of structures, recovering approximately $30 \%$ of the root length found in July 2015.

Higher increases in FRB (4.50 $\left.\mathrm{Mg} \mathrm{ha}^{-1}\right)$ and FRL $\left(3.8 \mathrm{~km} \mathrm{~m}^{-2}\right)$ for $2 \mathrm{~mm}$ diameter were found from March 2016 to July 2016, when the accumulated rainfall was $379.2 \mathrm{~mm}$, with predominance of the $1<\varnothing<2 \mathrm{~mm}$ class, presenting $3.39 \mathrm{Mg} \mathrm{ha}^{-1}$ and $2.9 \mathrm{~km} \mathrm{~m}^{-2}$, respectively (Table 2), representing $76 \%$ of the FRB and $100 \%$ of the FRL found in July 2015. After the end of the rainy season in July 2016, when the accumulated rainfall was 626 $\mathrm{mm}$ (Figure 2), the FRB was similar $(p<0.05)$ to that found in July 2015, except for November 2016. The water availability during the rainy season stimulates fine root production and, consequently, biomass accumulation (THAKUR et al., 2019). 
Table 2. Fine root biomass (FRB), fine root length (FRL), fine root specific length (FRSL) up to the soil depth of $30 \mathrm{~cm}$ in a seasonally dry tropical forest fragment in the Caatinga phytogeographic domain (SDTF-CPD), in Brazil.

\begin{tabular}{|c|c|c|c|c|c|c|c|c|}
\hline \multirow{2}{*}{$\begin{array}{c}\text { Root } \\
\text { diameter } \\
\text { class (mm) }\end{array}$} & \multirow[b]{2}{*}{ Values } & \multicolumn{7}{|c|}{ Collection date } \\
\hline & & July $15^{*}$ & $\begin{array}{c}\text { November } \\
15\end{array}$ & March 16 & July 16 & $\begin{array}{c}\text { November } \\
16\end{array}$ & March 17 & July 17 \\
\hline & \multicolumn{8}{|c|}{ FRB $\left(\mathrm{Mg} \mathrm{ha}^{-1}\right)$} \\
\hline \multirow{4}{*}{$\varnothing<2$} & Mean & $7.7 \mathrm{a}$ & 0.0 & $1.4 \mathrm{c}$ & $5.9 \mathrm{ab}$ & $4.6 \mathrm{~b}$ & $6.2 \mathrm{ab}$ & $6.6 \mathrm{a}$ \\
\hline & Median & 6.5 & 0.0 & 1.5 & 5.7 & 4.6 & 4.7 & 6.0 \\
\hline & SD & 5.0 & 0.0 & 0.6 & 2.0 & 1.6 & 3.6 & 2.7 \\
\hline & Mean & $2.9 \mathrm{a}$ & 0.0 & $0.8 \mathrm{c}$ & $1.9 \mathrm{ab}$ & $1.5 \mathrm{~b}$ & $1.7 \mathrm{ab}$ & $2.6 \mathrm{a}$ \\
\hline \multirow[t]{2}{*}{$\varnothing<1$} & Median & 2.4 & 0.0 & 0.8 & 1.8 & 1.4 & 1.7 & 2.2 \\
\hline & SD & 2.2 & 0.0 & 0.3 & 0.6 & 0.4 & 0.8 & 1.3 \\
\hline \multirow{3}{*}{$1<\varnothing<2$} & Mean & $4.8 \mathrm{a}$ & 0.0 & $0.6 \mathrm{c}$ & $4.0 \mathrm{ab}$ & $3.1 \mathrm{~b}$ & $4.5 \mathrm{a}$ & $4.0 \mathrm{ab}$ \\
\hline & Median & 4.2 & 0.0 & 0.7 & 3.6 & 3.1 & 3.1 & 3.9 \\
\hline & SD & 2.8 & 0.0 & 0.4 & 1.5 & 1.2 & 2.9 & 1.5 \\
\hline & \multicolumn{8}{|c|}{ FRL $\left(\mathrm{km} \mathrm{m}^{-2}\right)$} \\
\hline \multirow{4}{*}{$\varnothing<2$} & Mean & $5.0 \mathrm{~b}$ & 0.0 & $1.5 \mathrm{c}$ & $5.3 \mathrm{~b}$ & $3.6 \mathrm{bc}$ & $6.0 \mathrm{ab}$ & $7.6 \mathrm{a}$ \\
\hline & Median & 3.9 & 0.0 & 1.6 & 5.1 & 3.2 & 6.0 & 6.6 \\
\hline & SD & 3.2 & 0.0 & 0.4 & 2.4 & 1.3 & 2.0 & 3.1 \\
\hline & Mean & $2.3 \mathrm{ab}$ & 0.0 & $0.8 \mathrm{c}$ & $1.8 \mathrm{~b}$ & $1.2 \mathrm{bc}$ & $2.4 \mathrm{ab}$ & $3.8 \mathrm{a}$ \\
\hline \multirow[t]{3}{*}{$\varnothing<1$} & Median & 1.6 & 0.0 & 0.8 & 1.6 & 1.2 & 2.3 & 3.6 \\
\hline & SD & 1.8 & 0.0 & 0.3 & 0.9 & 0.3 & 0.6 & 1.8 \\
\hline & Mean & $2.7 \mathrm{ab}$ & 0.0 & $0.7 \mathrm{c}$ & $3.5 \mathrm{a}$ & $2.4 \mathrm{~b}$ & $3.6 \mathrm{a}$ & $3.7 \mathrm{a}$ \\
\hline \multirow[t]{2}{*}{$1<\varnothing<2$} & Median & 2.4 & 0.0 & 0.6 & 3.5 & 2.2 & 3.4 & 3.3 \\
\hline & SD & 1.5 & 0.0 & 0.3 & 1.6 & 1.0 & 1.7 & 1.5 \\
\hline & \multicolumn{8}{|c|}{ FRSL $\left(\mathrm{km} \mathrm{kg}^{-1}\right)$} \\
\hline \multirow{3}{*}{$\varnothing<2$} & Mean & $9.4 \mathrm{a}$ & 0.0 & $12.2 \mathrm{a}$ & $9.6 \mathrm{a}$ & $8.1 \mathrm{a}$ & $11.2 \mathrm{a}$ & $11.8 \mathrm{a}$ \\
\hline & Median & 8.7 & 0.0 & 9.8 & 9.5 & 6.8 & 12.8 & 11.5 \\
\hline & SD & 4.1 & 0.0 & 4.7 & 4.4 & 2.4 & 4.0 & 2.7 \\
\hline \multirow{3}{*}{$\varnothing<1$} & Mean & $13.1 \mathrm{a}$ & 0.0 & $10.5 \mathrm{a}$ & $10.2 \mathrm{a}$ & $8.3 \mathrm{a}$ & $16.4 \mathrm{a}$ & $15.5 \mathrm{a}$ \\
\hline & Median & 12.9 & 0.0 & 11.4 & 11.0 & 7.6 & 18.0 & 14.3 \\
\hline & SD & 6.6 & 0.0 & 2.5 & 4.1 & 2.6 & 6.8 & 4.6 \\
\hline \multirow{3}{*}{$1<\varnothing<2$} & Mean & $6.4 \mathrm{a}$ & 0.0 & $16.8 \mathrm{a}$ & $9.3 \mathrm{a}$ & $8.0 \mathrm{a}$ & $9.1 \mathrm{a}$ & $9.6 \mathrm{a}$ \\
\hline & Median & 6.8 & 0.0 & 12.9 & 8.8 & 6.7 & 9.5 & 10.1 \\
\hline & SD & 4.6 & 0.0 & 12.4 & 4.6 & 2.6 & 3.2 & 2.2 \\
\hline
\end{tabular}

* = sample control; $\mathrm{SD}=$ standard deviation. Means followed by the same letter in the rows are not different by the Kruskal-Wallis $\mathrm{H}$ test $(p<0.05)$ when comparing collections in the same class.

The FRL found in July 2016 was similar to that of the control (July 2015) (Table 2), denoting a higher investment in root length in the beginning of the development; however, this resulted in no significantly higher FRSL in March 2016. Approximately $68 \%$ of fine roots produced in July 2016 were from the $1<\emptyset<2 \mathrm{~mm}$ class, denoting that the predominant very fine roots in March 2016 increased rapidly in diameter during the rainy season. Roots of the $1<\varnothing<2 \mathrm{~mm}$ class predominated after July 2016 in the soil (Table 2) up to the last collection in July 2017. These results indicated that even after consecutive dry periods, two years were enough for the recovery of the root system of the SDTF. This response is probably due to the resilience of the plant species in the area, as reported by Santos et al. (2014). However, studies on fine root recovery for longer periods should be conducted.

The FRB, FRL, and FRSL presented decreases in the dry season from July to November of 2016. FRB decreased, on average, $20 \%$ in the three classes, reaching an FRB $(\varnothing<2 \mathrm{~mm})$ of $4.6 \pm 1.6$ $\mathrm{Mg} \mathrm{ha}^{-1}$. These decreases in FRB found in November
2016 resulted in significant differences when compared to those in the control; however, presenting no significant differences from those in July 2016. The FRL decreased, on average, 33\% in the three classes, resulting in an FRL $(\varnothing<2 \mathrm{~mm})$ of $3.6 \pm 1.3 \mathrm{~km} \mathrm{~m}^{-2}$. The FRSL $(\varnothing<2 \mathrm{~mm})$ decreased $15 \%$ in the three classes, reaching $8.1 \pm 2.4 \mathrm{~km} \mathrm{~kg}^{-1}$. These decreases represent the soil organic matter input. Therefore, the absence of rainfalls affects fine root production, as reported by Pinheiro, Costa, and Araújo (2013).

Fine roots had grown $1.2 \mathrm{~km} \mathrm{~m}^{-2}$ at the beginning of the second rainy season (March 2017), with a biomass production of $1.4 \mathrm{Mg} \mathrm{ha}^{-1}$ for the $1<\varnothing<2 \mathrm{~mm}$ class, and only $0.21 \mathrm{Mg} \mathrm{ha}^{-1}$ for the $\emptyset<1$ $\mathrm{mm}$ class. This distribution resulted in a higher FRSL for very fine roots $\left(16.43 \mathrm{~km} \mathrm{~kg}^{-1}\right)$, but not significantly differing from the other classes (Table $2)$. These results denote the recovery potential of the SDTF in relation to FRB $(\varnothing<2 \mathrm{~mm})$ in two years of regeneration for an accumulated rainfall of $626 \mathrm{~mm}$. The FRL $(\varnothing<2 \mathrm{~mm})$ increased faster in the first months of the experiment, and the FRL found in 
March 2016 presented no significant difference $(p<0.05)$ from the control. This shows that fine root growth is a strategy to explore a higher soil volume with lower investment of resources (PÉREZHARGUINDEGUY et al., 2013).

The effect of rainfall on fine root production was confirmed by the significance $(p<0.05)$ of coefficients of correlation between fine root growth and water availability variables (Table 3). The increases in FRB and FRL in all diameter classes showed a positive correlation $(p<0.05)$ to water availability, which was not significant $(p>0.05)$ only for FRB $(1<\varnothing<2 \mathrm{~mm})$. Fine roots respond rapidly to water stress and rainfall events (ALLEN et al., 2017), expressing a high inter- and intra-annual growth in tropical dry forests.

FRL $(\varnothing<1 \mathrm{~mm})$ was the fine root growth variable with higher sensitivity to water availability, it presented high significance $(p<0.001)$ to 4MAR, DWR3, DWR4 and was significant at $p<0.05$ for 3MAR and DWR4 $>5$ (Table 3). FRB $(\varnothing<1 \mathrm{~mm})$ was significant at $p<0.05$ for 3MAR, 4MAR, and DWR4, and presented high significance $(p<0.001)$ for DWR4 $>5$. Therefore, FRB and FRL $(\varnothing<1 \mathrm{~mm})$ showed high sensitivity to soil water availability variations. Fine root development as a response to rainfall depths starts in surface layers (ASSEFA et al., 2017; WIJK, 2011) and, then, to deeper layers depending on the rainfall depths and time for drainage of the water to deeper layers. FRD and FRSL presented no correlation to the water availability variables. This was probably due to the high variability of these variables $(\mathrm{CV}>50 \%)$.

Table 3. Spearman's coefficient of correlation between root growth and water availability variables in a seasonally dry tropical forest fragment in the Caatinga phytogeographic domain (SDTF-CPD), in Brazil.

\begin{tabular}{|c|c|c|c|c|c|c|c|}
\hline \multirow{2}{*}{$\begin{array}{l}\text { Root growth } \\
\text { variables }\end{array}$} & \multirow{2}{*}{$\begin{array}{c}\text { Diameter } \\
\text { Class (mm) }\end{array}$} & \multicolumn{6}{|c|}{ Water availability variables } \\
\hline & & 3MAR & 4MAR & DWR3 & DWR4 & DWR3 $>5$ & DWR4 $>5$ \\
\hline \multirow{3}{*}{ FRB } & $\varnothing<1$ & $0.928^{*}$ & $0.886^{*}$ & 0.580 & $0.886^{*}$ & $0.812 *$ & $0.943^{* *}$ \\
\hline & $1<\varnothing<2$ & 0.610 & 0.430 & 0.490 & 0.430 & 0.203 & 0.370 \\
\hline & $\varnothing<2$ & $0.812^{*}$ & 0.660 & 0.700 & 0.660 & 0.464 & 0.600 \\
\hline \multirow{3}{*}{ FRL } & $\varnothing<1$ & $0.812^{*}$ & $0.943^{* *}$ & $0.928^{* *}$ & $0.943^{* *}$ & 0.754 & $0.829^{*}$ \\
\hline & $1<\varnothing<2$ & $0.812^{*}$ & 0.660 & 0.700 & 0.660 & 0.464 & 0.600 \\
\hline & $\varnothing<2$ & $0.928^{* *}$ & $0.829^{*}$ & $0.812^{*}$ & $0.829^{*}$ & 0.522 & 0.710 \\
\hline \multirow{3}{*}{ FRD } & $\varnothing<1$ & -0.250 & -0.406 & -0.544 & -0.406 & -0.132 & -0.174 \\
\hline & $1<\varnothing<2$ & -0.174 & -0.029 & 0.058 & -0.029 & 0.116 & 0.086 \\
\hline & $\varnothing<2$ & -0.031 & -0.213 & -0.216 & -0.213 & -0.031 & -0.030 \\
\hline \multirow{3}{*}{ FRSL } & $\varnothing<1$ & 0.000 & 0.029 & 0.232 & 0.029 & 0.174 & 0.086 \\
\hline & $1<\emptyset<2$ & -0.116 & 0.086 & 0.348 & 0.086 & 0.406 & 0.143 \\
\hline & $\varnothing<2$ & -0.116 & 0.086 & 0.348 & 0.086 & 0.406 & 0.143 \\
\hline
\end{tabular}

$\mathrm{FRB}=$ fine root biomass; FRL $=$ fine root length; FRD $=$ fine root mean diameter; FRSL $=$ fine root specific length; $3 \mathrm{MAR}=3$-month accumulated rainfall before collection; 4MAR $=4$-month accumulated rainfall before collection; DWR3 = number of days with rainfall within 3 months before collection; DWR4 = number of days with rainfall within 4 months before collection; DWR3 $>5$ = number of days with rainfall above $5 \mathrm{~mm}$ within 3 months before collection; and DWR4 $>5=$ number of days with rainfall above $5 \mathrm{~mm}$ within 4 months before collection. * significant at $5 \%$ level; ** significant at $1 \%$ level.

\section{Spatial and temporal growth of fine roots}

In the first collections after the implementation of the ingrowth cores (November 2015) and in March 2016, the root vertical distribution was not evaluated. In November 2015 there was no fine root production in none of the layers due the absence of rainfalls in previous months (Figure 2). The layers were note collected in March 2016 because the soils were still unstructured due to the sieving during the implementation of ingrowth cores.

The FRB distribution of roots present in the 0
$-30 \mathrm{~cm}$ soil layer of the control were $48 \%$ for the 0 $10,31 \%$ for the $10-20$, and $21 \%$ for the $20-30 \mathrm{~cm}$ sublayer (Figure 4), presenting no significant differences $(p<0.05)$. Higher fine root concentration in surface layers was also found by Rosado et al. (2011), Assefa et al. (2017), and Katayama et al. (2019); it is due to the higher nutrient availability from the organic matter on the soil surface.

The results indicate that the fine root distribution throughout the $0-30 \mathrm{~cm}$ soil layer is dependent on the 4MAR (438 $\mathrm{mm})$, which represented $64 \%$ of the total rainfall in the year. Thus, the rainfall depth of $438 \mathrm{~mm}$ is enough to 
promote water storage in the first $30 \mathrm{~cm}$ of the soil, promoting the distribution of fine roots throughout the soil profile to search for water and nutrients. However, long-term studies are needed to confirm this hypothesis. Higher fine root concentration in the 0-30 $\mathrm{cm}$ during the rainy season in dry forests was also found by Pinheiro, Costa and Araújo (2013) and Wijk, (2011).

The FRL (July 2015) of the $\varnothing<2 \mathrm{~mm}$ and $\varnothing<1$ $\mathrm{mm}$ classes was higher in the $0-10 \mathrm{~cm}$ layer, differing significantly $(p<0.05)$ from the $20-30 \mathrm{~cm}$ layer (Figure 4). The increases in FRL were distributed into the $\varnothing<2 \mathrm{~mm}(49 \%)$ and $\varnothing<1 \mathrm{~mm}$ $(57 \%)$ classes, and concentrated in the $0-10 \mathrm{~cm}$ layer. The higher FRL in the $0-10 \mathrm{~cm}$ layer was found for roots in the $\varnothing<1 \mathrm{~mm}$ class $\left(1.3 \pm 0.6 \mathrm{~cm} \mathrm{~cm}^{-3}\right)$, denoting the higher investment in root length (FRESCHET et al., 2017; PÉREZHARGUINDEGUY et al., 2013). The higher growth of roots in the $\varnothing<1 \mathrm{~mm}$ class is because of the soil disturbance by the ingrowth core method (KATAYAMA et al., 2019), which disaggregated the soil structure.

This resulted in a FRSL $(\varnothing<1 \quad \mathrm{~mm})$ significantly $(p<0.05)$ higher in the $0-10 \mathrm{~cm}$ layer than those of deepest layer, denoting a higher increase in length per unit of biomass. FRSL is related to root structure, and is affected by root tissue density and root diameter (FRESCHET et al., 2017; PÉREZ-HARGUINDEGUY et al., 2013). Increases in FRSL is an alternative strategy of the plant to promote water absorption in water stress conditions (METCALFE et al., 2008), without increasing root biomass.

Decreases in FRSL $(\varnothing<1 \mathrm{~mm})$ in deeper layers was found only for the control (July 2015), possibly due to the higher soil density in deeper layers (Table 1). The implementation of ingrowth cores unstructured the soil due to the sieving for removal of roots. This procedure resulted in a soil with lower density in deeper layers, which may have contributed to a higher FRSL in these layers. Bejarano et al. (2010) report that soils with high density and resistance to penetration require higher energy for root development, increasing the energy cost for the plants and potentially reducing their root growth rate. Considering that the FRL did not increase in the $\varnothing<1 \mathrm{~mm}$ class in the $20-30 \mathrm{~cm}$ layer, the increase in FRSL in the $\varnothing<1 \mathrm{~mm}$ class is attributed to increases in root tissue density (PÉREZHARGUINDEGUY et al., 2013). Increases in root tissue density provides toughness and strength to roots, resulting in higher resistance to shrinking or rupture (CHIMUNGU; LOADES; LYNCH, 2015).

The homogeneous vertical distribution of
FRB, FRL, and FRSL in July 2016 (Figure 4) indicated a uniform soil water availability due to the accumulated rainfall $(379.2 \mathrm{~mm})$ from March 2016 to July 2016. Another factor that may have favored the deepening of fine roots is the unstructured soil due to the method used (KATAYAMA et al., 2019). Four months later (November 2016), the FRB, FRL, and FRSL decreased as the soil depth was increased (Figure 4). The occurrences of four consecutive months without rainfall (Figure 2) resulted in a high soil water deficit. The soil moistures in the dry season are $6 \%$ and $8 \%$ for $0-10 \mathrm{~cm}$ and $40-60 \mathrm{~cm}$ layers, respectively (MENDES et al., 2013), which is insufficient (COSTA et al., 2013) and the water is in non-available form to plants.

The vertical distribution of FRB, FRL and FRSL in the end of the dry season (November 2016) showed decreases as the soil depth was increased, with biomass allocation mainly in surface and intermediate layers (Figure 4). The four months without rainfall (Figure 2) resulted in low soil moisture and decreased fine roots as the soil depth was increased. This decrease may be an adaptation of the SDTF plants to water deficit, since the secondary root emission assists in the maintenance and absorption of solutes with lower energy consumption (ADIKU et al., 2000). The decreases in FRSL denote a higher investment in root structures.

The common long water deficit periods ( 8 to 10 months) in the Brazilian Semiarid region (ANDRADE et al., 2017) causes a low fine root production, mainly in deeper layers (WIJK, 2011; MAASS; BURGOS, 2011). The decreases in FRSL (Figure 4) denote a higher investment in root structures. Considering the low decreases in root mean diameter, the decreases in FRSL probably increased cell wall density (PÉREZHARGUINDEGUY et al., 2013). These decreases were significant $(p<0.05)$ for the $10-20$ and $20-30$ layer.

The FRB $(\varnothing<2 \mathrm{~mm})$ from November 2016 to March 2017 increased 50.23\%, 20.72\%, and 60.61\% in the $0-10,10-20$, and $20-30 \mathrm{~cm}$ layers, respectively, but with no significant differences $(p<0.05)$ between layers (Figure 4 , Table 4). FRL and FRSL growth were similar to those of the FRB, not differing significantly as the soil depth was increased. The accumulation of fine roots in the soil profile evaluated $(0-30 \mathrm{~cm})$ is related to the rainfalls, which accumulated $398.4 \mathrm{~mm}$ from November 2016 to March 2017, promoting the water storage in the whole soil profile. Gravimetric moisture of approximately $20 \%$ in deep layers $(40-60 \mathrm{~cm})$ are found in SDTF areas in the rainy season (MENDES et al., 2013) 

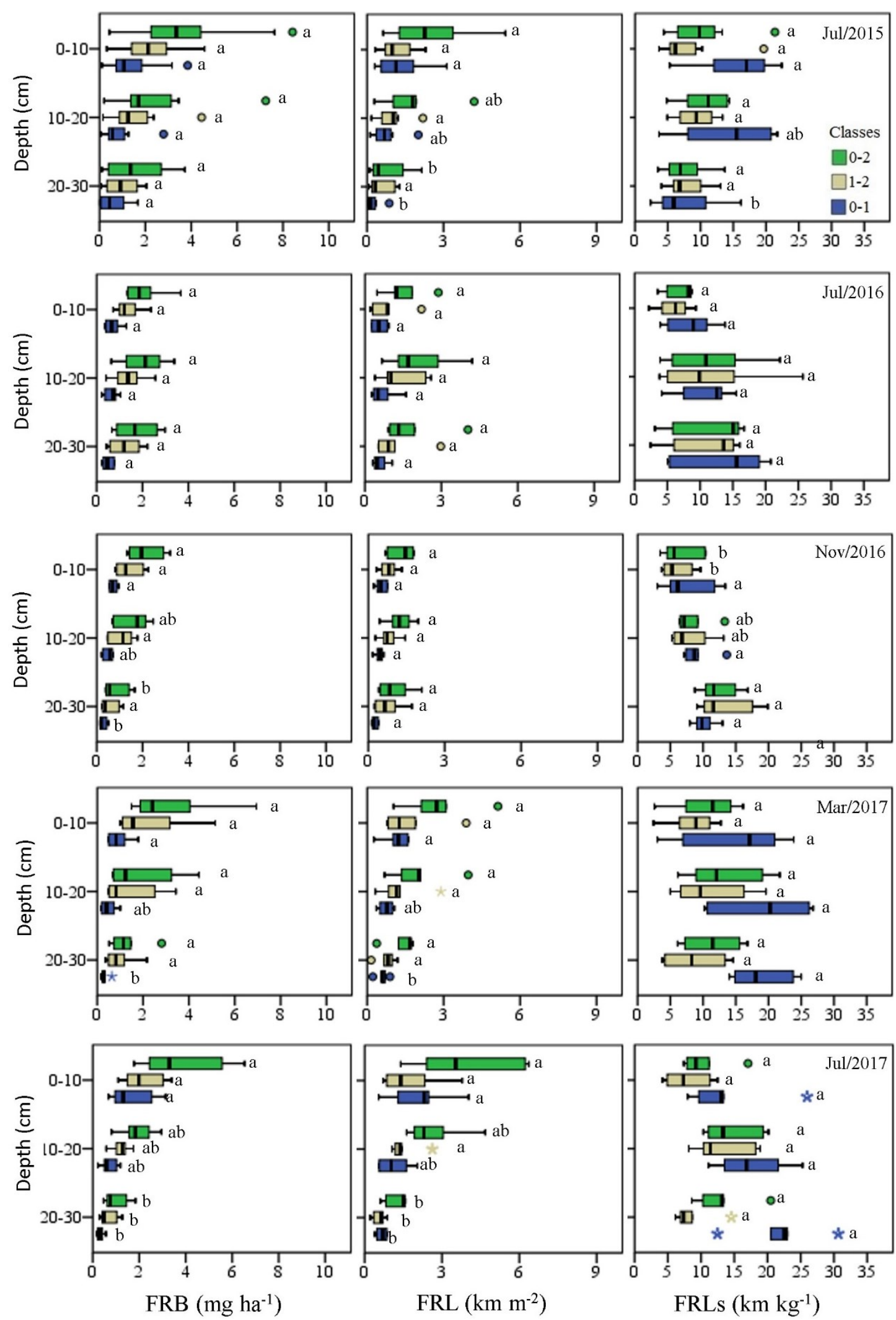

Means followed by the same letter, comparing the layers in the same class, are not significantly different at $5 \%$ probability by Kruskal-Wallis test. Outliers: ${ }^{\circ}=$ discrepant; $*=$ extreme.

Figure 4. Distribution of fine root biomass (FRB), length (FRL) and specific length (FRSL) in a seasonally dry tropical forest fragment in the Caatinga phytogeographic domain (SDTF-CPD), in Brazil. 
The root system deepens in search for nutrients dissolved in the soil solution to meet the high demand of the vegetative system (formation of growth and reproductive structures) during the beginning of the rainy season, when the soil water availability increases. The rainy season in the Brazilian Semiarid region is seldom longer than four months (ANDRADE et al., 2017). Therefore, plants in this region have a short time (approximately 4 months) with proper conditions for their development. The increases in very fine root $(\varnothing<1$ $\mathrm{mm}$ ) in the $20-30 \mathrm{~cm}$ layer in the beginning of the rainy season (March 2017) were not enough to reach the values found for the surface layer (Figure 4). Thus, very fine roots $(\varnothing<1 \mathrm{~mm})$ do not recover their biomasses and lengths in the beginning of the rainy season in deeper layers.

Table 4. Increases in root variables in the sublayers $(0-10,10-20$, and 20-30 cm) of soil of a seasonally dry tropical forest fragment in the Caatinga phytogeographic domain (SDTF-CPD), in Brazil.

\begin{tabular}{|c|c|c|c|c|c|c|c|c|c|}
\hline \multirow{3}{*}{$\begin{array}{l}\text { Diameter } \\
\text { class }(\mathrm{mm})\end{array}$} & \multicolumn{9}{|c|}{ Increases $(\%)$} \\
\hline & \multicolumn{3}{|c|}{$\begin{array}{c}\text { July } 2016 \text { to } \\
\text { November } 2016\end{array}$} & \multicolumn{3}{|c|}{$\begin{array}{l}\text { November } 2016 \\
\text { to March } 2017\end{array}$} & \multicolumn{3}{|c|}{$\begin{array}{l}\text { March } 2017 \\
\text { to July } 2017\end{array}$} \\
\hline & $0-10$ & $10-20$ & $20-30$ & $0-10$ & $10-20$ & $20-30$ & $0-10$ & $10-20$ & $20-30$ \\
\hline \multicolumn{10}{|c|}{ FRB $=$ fine root biomass } \\
\hline$\varnothing<1$ & 1.19 & -23.06 & -46.34 & 31.08 & -3.15 & 21.35 & 76.29 & 41.57 & -16.17 \\
\hline $1<\emptyset<2$ & 3.49 & -22.26 & -54.90 & 59.94 & 31.72 & 49.56 & -4.22 & -15.24 & -16.78 \\
\hline$\varnothing<2$ & 2.70 & -22.51 & -52.44 & 50.23 & 20.72 & 60.61 & 19.42 & -0.86 & -22.99 \\
\hline \multicolumn{10}{|c|}{$\mathrm{FRL}=$ fine root length } \\
\hline$\varnothing<1$ & -11.16 & -37.88 & -55.77 & 126.87 & 73.19 & 132.01 & 87.05 & 52.37 & 10.36 \\
\hline $1<\emptyset<2$ & -11.04 & -42.09 & -35.26 & 104.62 & 59.52 & 0.00 & 6.00 & 17.97 & -39.00 \\
\hline$\varnothing<2$ & -11.09 & -40.68 & -42.04 & 113.25 & 64.31 & 33.30 & 39.44 & 30.68 & -10.48 \\
\hline \multicolumn{10}{|c|}{ FRSL = fine root specific length } \\
\hline$\varnothing<1$ & -12.19 & -16.69 & -25.37 & 95.57 & 109.60 & 89.22 & -6.71 & -8.02 & 14.02 \\
\hline $1<\varnothing<2$ & 0.59 & -31.32 & 19.54 & 39.35 & 39.49 & -33.63 & -5.59 & 17.76 & -1.15 \\
\hline$\emptyset<2$ & -5.52 & -28.19 & 3.59 & 58.79 & 61.52 & -7.54 & -2.02 & 9.54 & 15.25 \\
\hline
\end{tabular}

The 0-10 and 20-30 $\mathrm{cm}$ soil layers presented significant differences in vertical distribution of the FRB $(\varnothing<2 \mathrm{~mm})$ in July 2017 due to increases in fine roots biomass in the $0-10 \mathrm{~cm}$ layer, as identified in March 2017 (Figure 4, Table 4). Decreases in FRB were found in the $1<\varnothing<2 \mathrm{~mm}$ class, mainly in the 10 -20 and $20-30 \mathrm{~cm}$ layers. Therefore, fine roots $(\varnothing<2$ $\mathrm{mm})$ increased $19 \%$ in the surface layer $(0-10 \mathrm{~cm})$ and decreased $23 \%$ in the deepest layer. The FRL $(\varnothing<2 \mathrm{~mm})$ presented similar results to those of the FRB $(\varnothing<2 \mathrm{~mm})$, with $50 \%$ of roots concentrated in the $0-10 \mathrm{~cm}$ layer. The high concentration of roots in the surface layer is due to the higher nutrient availability from the litterfall decomposition (ROSADO et al., 2011). The decreases in fine root mean diameter in the last collection denote their renewal and that they are being allocated mainly in layers with higher quantity of available nutrients (FRESCHET et al., 2017; IVERSEN et al., 2017).

\section{CONCLUSIONS}

The fine root growth is strongly limited in dry seasons, with decreases in root length in all soil layers and significant decreases (52\%) in biomass in deep layers. The root system development presents a fast response to rainfall events, mainly in root length. Fine roots begun to regenerate as rainfalls occurred in the beginning of the first rainy season. Two years were enough to identify the system root restauration in the seasonally dry tropical forest fragment in the Caatinga phytogeographic domain, even under consecutive dry periods. This fast development denotes the high soil water use efficiency of these root systems. The higher investment in root length per unit of biomass is a strategy to explore a greater soil volume with low energy investment. The highest root growth occurs in roots with diameters lower than $1 \mathrm{~mm}$, mainly in the surface layer. The decreases in fine root specific length denote a higher investment in root structure, which is caused by increases in the cell wall density, since increases in mean fine root diameter were not found.

\section{ACKNOWLEDGEMENTS}

The authors thank the Brazilian National Council for Scientific and Technological Development (CNPq) and the Foundation for Support of Scientific and Technological Development of the State of Ceará for the financial support to this research and for granting scholarships.

\section{REFERENCES}

ADIKU, S. et al. On the simulation of root water extraction: examination of a minimum energy hypothesis. Soil Science, 165: p. 226-236, 2000. 
ALLEN, K. et al. Will seasonally dry tropical forests be sensitive or resistant to future changes in rainfall regimes? Environmental Research Letters, 2: 1$15,2017$.

ANDRADE, E. M. et al. Uncertainties of the rainfall regime in a tropical semi-arid region: the case of the State of Ceará. Revista Agro@mbiente On-line, 10: 88-95, 2016.

ANDRADE, E. M. et al. Water as capital and its uses in the Caatinga. In: SILVA, J. M. C.; LEAL, I. R.; TABARELLI, M. (Eds.) Caatinga: the largest tropical dry forest region in South America. Berlin: Spring, 2017. v. 1, cap. 10, p. 281-302.

ANDREASSON, F. et al. Comparison of ingrowth cores and ingrowth meshes in root studies: 3 years of data on Pinus pinaster and its understory. Trees, 30: 555-570, 2016.

AQUINO, D. N. et al. Belowground carbon and nitrogen on a thinned and un-thinned seasonally dry tropical forest. American Journal of Plant Sciences, 8: 2083-2100, 2017.

ASSEFA, D. et al. Fine root dynamics in afromontane forest and adjacent land uses in the northwest ethiopian highlands. Forests, 8: 1- 21, 2017.

BEJARANO, M. D. et al. Effects of soil compaction and light on growth of Quercus pyrenaica Willd. (Fagaceae) seedlings. Soil and Tillage Research, 110: 108-114, 2010.

CASTANHO, D. A. et al. Potential shifts in the aboveground biomass and physiognomy of a seasonally dry tropical forest in a changing climate. Environmental Research Letters, 15: 1-11, 2020.

CHIMUNGU, J. G.; LOADES, K. W.; LYNCH, J. P. Root anatomical phenes predict root penetration ability and biomechanical properties in maize (Zea Mays). Journal of Experimental Botany, 66: 31513162, 2015.

COSTA, C. A. G. et al. Spatial behaviour of soil moisture in the root zone of the Caatinga biome. Revista Ciência Agronômica, 44: 685-694, 2013.

COSTA, T. L. et al. Root and shoot biomasses in the tropical dry forest of semi-arid Northeast Brazil. Plant and Soil, 378: 113-123, 2014.

ERKTAN, A.; MCCORMACK, M. L.; ROUMET, C. Frontiers in root ecology: recent advances and future challenges. Plant and Soil, 424: 1-9, 2018.

FRESCHET, G. T. et al. Climate, soil and plant functional types as drivers of global fine root trait variation. Journal of Ecology, 105: 1182-1196, 2017.

GALKOVSKYI, T. et al. GiA Roots: software for the high throughput analysis of plant root system architecture. BMC Plant Biology, 12: 2-12, 2012.

IVERSEN, C. M. et al. A global Fine-Root Ecology Database to address below-ground challenges in plant ecology. New Phytologist, 215: 15-26, 2017.

KATAYAMA, A. et al. Estimating fine root production from ingrowth cores and decomposed roots in a bornean tropical rainforest. Forests, 10:1-13, 2019.

MAASS, M.; BURGOS, A. Water dynamics at the ecosystem level in Seasonally Dry Tropical Forests. In: DIRZO, R. et al. (Eds.). Seasonally Dry Tropical Forests: ecology and conservation. Washington, DC: Island Press, 2011. v. 1, cap. 9, p. 141-156.

MENDES, M. M. S. et al. Ecophysiology of deciduous plants grown at different densities in the semiarid region of Brazil. Theoretical and Experimental Plant Physiology, 25: 94-105, 2013.

METCALFE, D. B. et al. The effects of water availability on root growth and morphology in an Amazon rainforest. Plant and Soil, 311: 189-199, 2008.

MURPHY, P. G.; LUGO, A. E. Ecology of tropical dry forest. Annual Review of Ecology and Systematics, 17: 67-88, 1986.

PEREIRA JÚNIOR, L. R. et al. Carbon stocks in a tropical dry forest in Brazil. Revista Ciência Agronômica, 47: 32-40, 2016.

PÉREZ-HARGUINDEGUY, N. et al. New handbook for standardised measurement of plant functional traits worldwide. Australian Journal of Botany, 61: 167-234, 2013.

PERSSON, H. A. The distribution and productivity of fine roots in boreal forests. Plant and Soil, 71: 87 $-101,1983$.

PINHEIRO, E. A. R.; COSTA, C. A. G.; ARAÚJO, J. C. Effective root depth of the Caatinga biome. Journal of Arid Environments, 89: 1-4, 2013.

PINNO, D. B. et al. Fine root dynamics of trembling aspen in boreal forest and aspen parkland in central Canada. Annals of Forest Science, 67: 1-6, 2010.

ROSADO, B. H. P. et al. Fine root biomass and root length density in a lowland and a montane tropical rain forest, SP, Brazil. Biota Neotropica, 11: 203- 
$209,2011$.

SANTOS, H. G. et al. Sistema Brasileiro de Classificação de Solos. 5. ed. Brasília, DF: Embrapa, 2018. 356 p.

SANTOS, M. G. et al. Caatinga, the Brazilian dry tropical forest: can it tolerate climate changes? Theoretical and Experimental Plant Physiology, 26: 83-99, 2014.

SOLLY, E. F. et al. Unravelling the age of fine roots of temperate and boreal forests. Nature Communications, 9: 1-8, 2018.

THAKUR, T. K. et al. Assessment of biomass and net primary productivity of a dry tropical forest using geospatial technology. Journal Forest Resource, 30: 157-170, 2019.

WIJK, M. T. V. Understanding plant rooting patterns in semi-arid systems: an integrated model analysis of climate, soil type and plant biomass. Global Ecology and Biogeography, 20: 331-342, 2011. 